\title{
The Nature and Missionary Role of the Lay People in the Light of Vatican II; Convenience or Conviction?
}

\begin{abstract}
The nature and the missionary role of the laity in the church is one of the issues currently vital to the church and theologians. From the Second Vatican Council (1962-1965) perspective, the word laity is technically understood to mean all the faithful except those in holy orders and those in the state of religious life specially approved by the Catholic Church (LG31). These faithful are by baptism made one with Christ and constitute the People of God; they are sharers in the priestly, prophetic and kingly functions of Christ; and they carry out for their own part the mission of the whole Christian people in the church and in the world. However, the distinction between the ordained and the lay is a real one. A great deal of attention has been paid to the ordained ministry of the Church, its nature, its authority and its functions. The laity tends, by way of contrast, to be taken very much for granted, as though in their case no special problems arise. This study discusses the nature, role, and participation of lay people in the mission of the Church as proposed by the Second Vatican Council. It treats succinctly the historical development of the Laity and the challenges and opportunities inherent in their mission.
\end{abstract}

Keywords: Mission, Evangelization, Communion, Convenience, Conviction, Lay faithful, Clergy, the baptized, Christifideles; aggiornamento, Apostolicam Actuositatem; Lumen Gentium.

\section{FRANCIS APPIAH-KUBI \& ROBERT YEBOAH}

${ }^{1}$ FRANCIS APPIAH-KUBI, PhD is a Senior Lecturer in the Department of Religious Studies, Kwame Nkrumah University of Science and Technology, Kumasi-Ghana. Email: frkubi@gmail.com.

Robert Yeboah is a second-year seminarian in Theology at the St. Gregory the Great Major Provincial Seminary, Kumasi. He holds BA degree in Religious Studies and Sociology from the University of Ghana, Legon.

\author{
Manuscript \\ Received 18th March 2020, \\ Accepted 8th May 2020, \\ Published online 12th May 2020.
}

\section{INTRODUCTION}

The Second Vatican Council, also called Vatican II, (1962-65), ${ }^{2}$ is the 21 st ecumenical council of the Roman Catholic Church, announced by Pope John XXIII on January 25, 1959, as a means of spiritual renewal for the church and as an occasion for Christians separated from Rome to join in a search for Christian unity. It is considered to be the last and the greatest Ecumenical Council in the history of the Catholic Church in the modern world. It deals with issues relating to the church's self-understanding and her mission in the modern world. One of the crucial guiding principles of the council is aggiornamento, "bringing up to date", a renewal and refreshing of the church in her own understanding and her mission in the world. The church opens up to the world and thus reads prudently the signs of the times. The sixteen documents of Vatican II has four constitutions, nine decrees and three declarations. The constitutions are the most weighty and formal documents, dealing with substantial matters, usually of a doctrinal nature. Whereas the decrees are statements that may be of a doctrinal or pastoral nature and often give guidelines for appropriate updating, the declarations deal with topics of current interest, especially insofar as they raise pastoral concerns.

One of the 16 documents of the Second Vatican Council is the Decree on the Apostolate of Lay People: Apostolicam Actuositatem, promulgated on 18 November 1965. This document deals specifically with the theme of the Apostolate

\footnotetext{
The official text of the documents of Vatican II is in Latin and can be found in Sacrosanctum Oecumenicum Concilium Vaticanum II: Constitutiones, Decreta, Declarationes, Vatican 1966.
} 
of Lay People. It builds on the insights of the second Vatican Council's dogmatic constitutions on the church, Lumen Gentium. The Decree describes the special status of lay people regarding their nature and their active involvement and participation in the overall mission of the church. A pastoral council dedicated to "imparting an ever increasing vigor to the Christian life of the faithful" 3 through a renewal based on the conversion and the universal call to holiness ${ }^{4}$ could not fail to address specifically the numerically largest group in the church, the laity. They are on the front lines of the church's life and they ought to have a clearer consciousness not only of belonging to the Church, but of being the Church. They are therefore a significant force within the overall mission of the church today. The mission of the church is a communal mission, meaning all members of the church have a duty to carry on. The contribution of each member of the Church towards her mission is indispensable and cannot be substituted by others.

\section{Historical Development of the term Laity}

As Vatican II's Dogmatic Constitution on the Church reminds us, the New Testament writers use the term laos (people) to refer to all the members of the Church: ${ }^{5}$ it designates those who constitute the spiritual Israel, the new "People of God" (laos theou). Since in this context the term continues to bear the Old Testament sense of consecration or election, the first Christians are routinely referred to as the elect, the saints of God. ${ }^{6}$ In his classic study, however, de la Potterie argues that while laikos derives from laos, the adjective never takes on the rich meaning traditionally associated with the noun. Rather, laikos maintains its classical sense of "the people" in contrast to the leaders; furthermore, the term acquires from Hellenistic Judaism the additional nuance, "that not consecrated for service in divine worship." In a Christian context therefore laikos refers, first to those who are not leaders of the community, and second, to those who exercise no cultic function - those who are neither priest, nor deacon. ${ }^{8}$

In the Bible, "to designate Israel as God's chosen people, the Hebrew OT uses 'am', a word translated in the Septuagint by laos" (cf. Ex 19:3-7; Dt 7:6; 14:2). ${ }^{9}$ Thus, in the OT and NT the two words am and laos have the same meaning and are used to designate all the people of the covenant. The NT also emphasizes this element but later it changed for emphasizing "the former as the real church." ${ }^{10}$ Later the church used the word laos to designate those members who contrast with their leaders of community. When then did the idea of a group of people in the church called the "laity" as distinct from and unequal to another group called "clergy" emerge and why? Every statement about the history of the laity presupposes a certain ecclesiology. If we follow Yves Congar's classical approach, the Church in its fullest mystery is a union of two elements: it is a fellowship of persons in Christ and the totality of means to that fellowship; it is community and institution; life and structure; structure is empty without life and life needs structures as an integrating principle. ${ }^{11}$ Regardless of the distortions of these two elements in the development of the church's life and this is the fascinating and sometimes tragic substance of the history of ecclesiology they form an intimate and inseparable unity.

According to Congar, the great achievement of Vatican II, was precisely the affirmation of this unity: the wonderful diversity of the Church, the hierarchy, clergy, laity, religious, each with their own place and responsibility, all called to holiness as the People of God made one in mystery with the unity of the Father, Son and Holy Spirit. Such a unity is rooted in the Church's foundation in the act of God in Christ ${ }^{12}$. All were called to the Kingdom and consecrated a royal priesthood, a chosen people (1 Pet 2:9-14). He further argued that, while there was never a period in the Church of an undifferentiated charismatic community, there is no New Testament vocabulary to express the distinction of clergy and laity. ${ }^{13}$ During the first few generations, all were filled with the same eschatological expectation. The real distinction, remarked G.H. Williams was not so much between clergy and laity, though even in the absence of terminology such theologically important distinctions were never denied, ${ }^{14}$ but rather between those called to the Kingdom and those not, between the holy people of God and the unredeemed world. "Laity" were hardly considered "of the world" as they are today. Lay persons were active in the early Church in liturgy and sacraments and participated with presbyters and bishops in the corporate discipline of the Church. They shared in evangelizing and the teaching of the faith and in the service of the whole community. ${ }^{15}$

Dogmatic constitution on Liturgy, Sacrosanctum Concilium (SC), 1.

Cf. Dogmatic Constitution on the church, Lumen Gentium (LG), 39-42.

$L G 9$

J.A. Komonchak \& M. Collins, The New Dictionary of Theology, Bangalore: Theological Publications in India, 2014, 558-559

I. de la Potterie, «L'Origine et le sens primnitif du mot "laïc" », in Nouvelle Revue Theologique, 80,840

A. Roberts, J. Donaldson \& A.C. Cleveland, Ante-Nicene Fathers, New York:, Christian Literature Publishing Co., $1885,3$.

G. O'Collins, (SJ.) \& E. Farrugia, (S.J), (eds.), "Laity”, A Concise Dictionary of Theology: Quezon City:, Claretian Publications, $2001,133$.

G. O'Collins, (S.J) \& E. Farrugia, (S.J). (eds.), "Laity", 133.

Y. Congar, Lay People in the church: a study for a theology of the laity, Westminster:, Newman Press, 1957, $28-58$.

Cf. $L G 31$

Y. Congar, Lay People, 4-5

14 G.H. Williams, "The Ancient Church," in H.R. Weber \& S.C. Neill, (eds.) The Layman in Christian History, Philadelphia:, Westminster Press, 1963, 14

15 E. Schillebeeckx, The Mission of the Church New York:, Seabury, 1973, 117-118 
By the middle of the third century, with the influx of many nominal Christians, the bond of unity was no longer the eschatological hope but sacraments administered by the clergy. The understanding of the church changed as it took on greater temporal form; greater distinctions were made between those willing to live and die as martyrs and those content to live by minimal gospel precepts. ${ }^{16}$ The peace of Constantine made these changes all the more significant. The earlier distinction between the eschatological community, united in different functions, and the unredeemed world became, with the advent of a world which was now Christian, a distinction within the Church itself. The Apostolic Constitutions ${ }^{17}$ early in the fourth century defined the role of the laity with more precision, putting the bishop more clearly in charge, and separating the clergy and the laity in worship. Lay persons were gradually eased out of positions of financial authority in the Church in the fourth and fifth centuries. Important issues were no longer decided upon, as Cyprian had suggested, "with the consent of the whole people." Pope Leo banned the laity from preaching, and Pope Gregory replaced all of his lay servants with clerics or monks. ${ }^{18}$

\section{Emergence of the Laity as Distinct from and Subordinated to the Priestly Group}

From the foregone, we remark that in the New Testament there is no distinction of Christians into two categories that are later known as "clergy" and "laity," the former different from the latter by their "priesthood." Rather, all Christians are priests by virtue of baptism, sharing equally in the one priesthood of Jesus Christ. Also in virtue of baptism, in which the gifts of the Holy Spirit are diversely communicated, Christians are called to perform different and mutually complementary functions which are all necessary for the well-being of the church. It is clear then that for the New Testament there is only one priest, Jesus Christ, and that the whole people of God shares equally in this priesthood of Christ through baptism (the baptismal priesthood). Because of this common priesthood, all Christians are fundamentally equal, endowed with the same dignity and the same vocation to holiness. However, this fundamental equality among Christians does not mean that they all do the same things. There are an endless variety of functions all of which are necessary for the well-being of the church and must be exercised to build up the body of Christ. If these functions are to be put into a hierarchy, the criterion is neither power nor holiness. That is, no function is superior to another in terms of power, and no function is better than another in terms of holiness: they are all mutually complementary. The only criterion for the distinction of functions in the church is service-in-love remarked Alexandre Faivre. For him, "There is no question of a hierarchy of power or of holiness. What is involved is a hierarchy of service." 19

The Church from the beginning of the Dark Ages to the Reformation is a millennium of complex history, of growth and decline, of change and stagnation, of contrasts of all sorts. Until the beginning of the fourth century, and as Charles M. Dahl rightly argued Christianity had been a forbidden religion and bloody persecutions had been periodically conducted against Christians. ${ }^{20}$ However, with the conversion of Emperor Constantine (274 or 288-337) and with the so-called Edict of Milan in 313 Christianity became first tolerated and, with astounding rapidity, under the reign of Emperor Theodosius I (379-395) became the only tolerated and imperial religion. ${ }^{21}$ This new legal status brought immense changes to the organization of Christianity, political power began to interfere in the life of the church so much so that the Church's organization mimicked that of the state. Gradually, the importance and power of the bishop paralleled that of the district over which he presided. Thus, a bishop of a metropolis would supervise what was happening in the bishoprics within his area, and hence there began to be a "hierarchy" among the bishops.

With the end of the Empire, the cultural power of education became the exclusive province of the church. Clericus became synonymous with "literate" and laicus "illiterate." The antithesis between laity and clergy was sharpened; the laity were the ignorant of the Church and almost all of knowledge of the laity in this period comes through the exclusive eyes of the clergy. Laity became more and more isolated not only by language, since Latin was no longer the common language, but also by intellectual discipline ${ }^{22}$. C. Brooke, a historian did not hesitate to decry: "The view of the Church as the community of the faithful was not completely lost sight of by the theologians, but in the government of the Church and in everyday speech, the Church was equivalent to the clerical order. The clergy were the shepherds, the laity sheep. ${ }^{23}$ " Effectively, the clergy became not only an ecclesial category but also a social class. The hierarchy with its triple rank -bishop, priest, and deacon - became a ladder for ecclesiastical power and honors and the clerical. The characteristics proper to lay persons state itself became a career of many steps, the lower leading

\footnotetext{
G.H. Williams, "The Ancient Church", 29 unknown.

18 G.H. Williams, "The Ancient Church", 29

19 Alexander Faivre, The Emergency of Laity in the early Chruch, New York:, Paulist Press, 1990, 9

20 C.M. Odahl, Constantine and the Christian Empire, London:, Routledge, 2004, 1.

21 Cf. C.M. Dahl, Constantine, 1-2

22 Cf. C. Brooke, "The Church of the Middle Ages," in H.R. Weber \& S.C. Neill, The Layman, 113-117.

23 C. Brooke, "The Church of the middle Ages", 113
}

17 The Apostolic Constitutions or Constitutions of the Holy Apostles is a Christian collection of eight treatises which belongs to the Church Orders, a genre of early Christian literature, that offered authoritative "apostolic" prescriptions on moral conduct, liturgy and Church organization. The work can be dated from 375 to $380 \mathrm{AD}$. The provenance is usually regarded as Syria, probably Antioch. The author is 
to the higher by a process of promotion. Given this situation, it is not surprising that some people would join the clergy for less than honorable motives. ${ }^{24}$

The distinction between clergy and laity was not only one of education but also in the understanding of Christian life and Christian perfection, an understanding which was, of course, exclusively the clergy's. The Bull of Urban II in 1092 cited by Y. Congar, advocates this view: "From the beginning, the Church has offered two kinds of life to her children: one to help the insufficiency of the weak, another to perfect the goodness of the strong. ${ }^{25}$ There was a $d u o$ genera Christianorum (two kinds of Christians) a true Christian, consistent with the apostolic life, left the world for a life of continence. Life in the world, including marriage and a family, was considered a compromise ${ }^{26}$. A lamentable result is the lowering of the status of the lay person in the church, whose distinction from the clergy was signaled not only by liturgical rituals, as we have seen above, but also by the economic, social and political rank. The low esteem in which the laity were held is indicated by the punishment a member of the clergy would be subjected to in case of misbehavior. This punishment consists in being "reduced" or "deposed" or "demoted" or "downgraded" from the clerical state to the lay state, with the loss of all the rights and privileges of the clerical grade from which one has fallen. The lay state then is the lowest possible state in the church, a shameful condition, worse than excommunication, to which a cleric is condemned for his sinful conduct.

Political and economic factors of enormous complexity further enhanced the distinction between clergy and laity. ${ }^{27}$ The only laymen who could confront the power of the clergy were the lay rulers, the emperors, the monarchs and the princes. The antithesis between clergy and laity took on a much narrower and insidious form, between clerical political power and lay political power. This is typified, according to E. Schillebeekx, in the struggle between King Philip the Fair and Pope Boniface VIII, representatives of the imperium and sacerdotium in conflict with each other. The pope states that the "Laity has always been hostile to the clergy; antiquity teaches us this and it is only too clear in our times. ${ }^{28}$ His attitude of estrangement reflects the historical conditions of the period, while revealing the Church's self-understanding which would have profound ecclesiological effects on the following centuries. The Church, in an effort to defend her identity against a variety of lay heresies, continued to define herself in terms of her hierarchical and institutional form. This, unfortunately, spawned a backlash of more anti-clericalism ${ }^{29}$ spiritualism and later conciliarism from the twelfth century through the period of the Reformation.

The clergy or lay distinction affected the development of Christian spirituality as well. Once the clergy became identified with realm of the sacred, it was natural to link the laity with the profane, the temporal. From the beginning, Christian theologians tended to be ambivalent about the world. On the one hand, because of its divine source, they fully accepted the fact of creation's essential goodness. On the other, since it proves to be a source of evil and distracts the Christian from spiritual things, the early Church Fathers also regarded the world with suspicion, even contempt. Since it was the clergy who were in a position to articulate the Christian worldview, they were prone to define holiness in terms of a flight from the world, thus repudiating the very structures and values natural to the lay estate. In time it was simply accepted that if one wishes to take seriously his or her Christian calling, this could be successfully done only within the framework of monasticism.

\section{The Mission of the Laity in the Church}

The word mission is derived from the Latin word "mittere" which means "to send" 30 . Commonly, this definition expresses three elements contained in the word mission: the agent who sends, the receiver to whom something is sent, and the thing or object sent or the content. In the church the word mission can be understood in two different senses, in a narrower sense and in a broader sense: The first or narrow sense relates to the specific missionary activities of the church addressed to those people and cultures still not directly affected by the Good News. The second sense refers basically to "everything that the church does at the service of the Kingdom of God." ${ }^{11}$ This definition reveals that the mission of the church refers to both activities of the church realized within (missio ad intra) and outside (missio ad extra) the Church. All activities of the Church are to nourish the faith of its members so that they can know more about what they believe and realize their mission as full members of the church in the world. At the same time the mission towards the world is to present the salvation of God to all nations and their cultures so that the kingdom of God can be effected in them all.

Every missionary activity of the Church originates from Trinitarian mission which is also called missio Dei, the

\footnotetext{
C. Brooke, "The church in the middle Ages," 115

Y. Congar, Lay People, 12.

Y. Congar, Lay People, 12.

Cf. R. W. Southern, "The Church of the Dark Ages," in H.R. Weber \& S.C. Neill, The Layman, 97-102

E. Schillebeeckx, Mission of the Church, 31.

Cf. Congar, Lay People, 28-54.

G.M. Greenewald, "Missions, Divine”, New Catholic Encyclopedia. New York:, McGraw Hill Book Company, $1967,928$.

W. McConville, (OFM), "Mission”, in J.A. Komonchak, M. Collins \& D.A. Lane (eds.) The New Dictionary of Theology, Collegeville:, Minnesota, 1991, 668.
} 
divine mission, by which the Father sent His Son Jesus Christ into the world. After accomplishing his mission the Son sent the Holy Spirit to his followers ${ }^{32}$ and consequently the Church was sent to proclaim the good news. Jesus invited all people to participate in his mission by choosing first the twelve apostles to preach and witness the Good News and serve others in love (Matt. 4:17-22; Mark 1:14-20; Luke 5:1-11). To continue his mission, Jesus promised to send the Holy Spirit (John 15:26; 16:5-15) which was realized in the Pentecost. The Holy Spirit dwells upon the Church to empower all members both lay and clergy alike, to manifest the presence of God through Christ within the mission of the Church in the World.

\section{Some Fundamental Aspects of the Missionary role of the Laity}

In the light of Vatican II, the primordial and most fundamental aspect of the lay faithful's vocation is their call to "the perfection of charity" 33 . This divine call, commented Pope John Paul II "made by the Father in Christ through the Holy Spirit reveals their true dignity." ${ }^{34}$ All the members of the Church receive from God and share the same vocation to holiness, inseparable from their dignity as baptized, namely: the call to fullness in Christian life and to perfection of charity in their particular state of life. ${ }^{35}$ As members of the chosen people of God, "they share a common dignity from their rebirth in Christ. They have the same filial grace and same vocation to perfection." ${ }^{\prime 36}$ Pope John Paul II in his apostolic exhortation, Christifideles Laici points out the concrete consequences of this call, by referring to the letter to the Colossians (cf. Col 3: 17) as presented in paragraph four of Apostolicam Actuositatem of the Second Vatican council: "Such a vocation, then, ought to be called an essential and inseparable element of the new life of Baptism, and therefore an element which determines their dignity. At the same time the vocation to holiness is intimately connected to mission and to the responsibility entrusted to the lay faithful in the Church and in the world." ${ }^{\prime 7} \mathrm{He}$ consistently affirmed that, "Neither family concerns nor other secular affairs should be excluded from their religious programme of life" ${ }^{38}$, for the vocation of the lay faithful to holiness implies that life according to the Spirit expresses itself in a particular way in their involvement in temporal affairs and in their participation in earthly activities". ${ }^{39}$

The Pope further argued that, "the unity of life of the lay faithful is of the greatest importance: indeed they must be sanctified in everyday professional and social life. Therefore, to respond to their vocation, the lay faithful must see their daily activities as an occasion to join themselves to God, fulfill his will, serve other people and lead them to communion with God in Christ." ${ }^{40}$ The laity fulfill this mission of the church in the world especially by conforming their lives to their faith so that they become the light of the world as well as by practicing honesty in all their dealings they attract all to the love of the true and the good and finally to the Church and to Christ. They fulfill their mission also by fraternal charity which presses them to share in the living conditions, labors, sorrows, and aspirations of their brethren with the result that the hearts of all about them are quietly prepared for the workings of saving grace ${ }^{41}$. Their responsibility, in particular, is to testify how the Christian faith constitutes the only fully valid response to the problems and hopes that life poses to every person and society. In this respect, the basic charge which comes together with holiness is the renewal of Christian life in compliance with the Gospel. How are they to carry such missionary responsibility?

\section{- Communion and mission}

It is remarkable to acknowledge that the lay faithful have to proclaim the Gospel, presenting the word of God even to the people who are far removed from it. This is the command of Jesus Christ "Go into all the world and preach the Gospel to the whole creation." (Mk 16:15) Their mandate to proclaim the word of God emanates theologically from the model of the Church as communion, which is by its very nature a missionary community, led by the Holy Spirit: "Communion begets communion: essentially it is likened to a mission on behalf of communion. ... Communion and mission are profoundly connected with each other, they interpenetrate and mutually require each other to the point that communion represents both the source and the fruit of mission: communion gives rise to mission and mission is accomplished in communion." ${ }^{42}$. The Church is aware that the communion received by her as a gift is destined for all people, the laity inclusive. Thus the Church feels she owes to each individual and to humanity as a whole the gift received from the Holy Spirit that pours the charity of Jesus Christ into the hearts of every believer, as a mystical force for internal cohesion

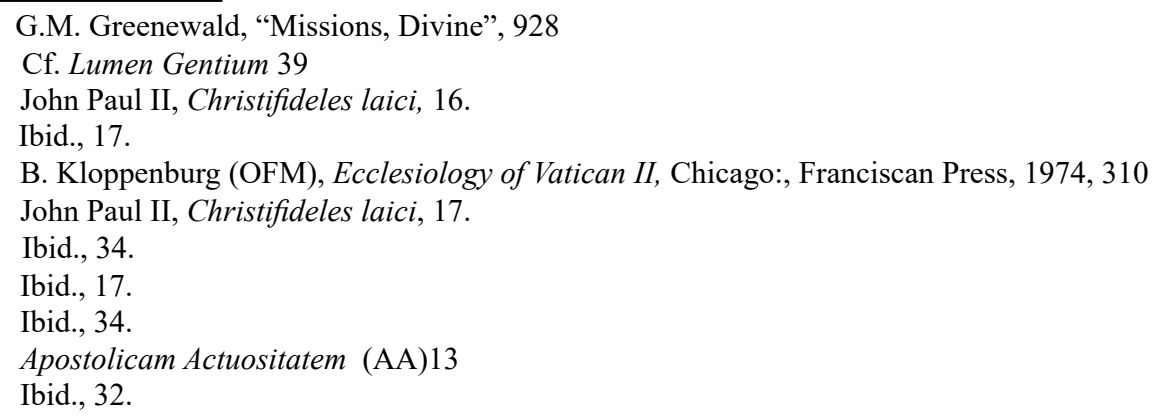


and external growth. ${ }^{43}$ The character of the Church as mission implies that the lay faithful's primary and fundamental task is to proclaim the Gospel. In his commentary on the conciliar decree Apostolicam Actuositatem which states that "The Christian vocation is by its very nature a vocation to the apostolate", the theologian Ratzinger makes an insightful comment:

[This vocation] thus involves the basic understanding of Christian existence as dynamism. The mission can no longer be seen as external activity, superficially imposed on a static Christianity; being a Christian means in and of itself to go beyond oneself. This being a Christian is therefore characterized by a missionary imprint and as a result must express itself - in every time and in every true believer - as an external activity, put into motion so as to fulfill his deepest nature. ${ }^{44}$

By announcing the Gospel the lay faithful participate in the primary task of the Church, and thus they come to build and shape the community of faith that confesses the faith in full adherence to the Word of God which is celebrated in the Sacraments, and lived in charity, the principle of Christian moral existence.

\section{- Transformative social mission}

We can, consequently remark that the laity continues to play their respective role in the current re-evangelization activity of the church. With the effect of consumerism and secularism, many are led to a life as if God does not exist. Lack of faith and practice of religion causes serious problems of the age. Moral and spiritual legacy is at risk after the period of declared atheism. Only re-evangelization can guarantee the growth of a clear and deep faith and serve to make the gospel message a force for authentic freedom. In this venture of re-evangelization which is entrusted to the Church, the lay faithful possess an active and responsible share in the transformation of the society. They are placed at a more strategic position to restore the moral fabric of society which is damaged with the doubts and despair of separation of the faith from the life..$^{45}$ They participate in this mending attempt individually or in a certain group on condition that they are always in conformity with the life and the mission of the Church. They are therefore called by God that, being led by the spirit to the Gospel, they may contribute out of conviction of their baptismal grace, to the sanctification of the world, as from within like leaven, by fulfilling their own particular duties.

Furthermore, the lay faithful has the duty to promote the dignity of the human person and their rights. It is essential to preserve the dignity of a person who is a center of all existence. The pastoral constitution of the Second Vatican Council Gaudium et Spes states without ambiguity that, among all other earthly beings, only a man or a woman is a person, a conscious and free being and, precisely for this reason the center and summit of all that exist on the earth. ${ }^{46}$ Being created by God in His image, all human persons are equal to one another, so there cannot be accepted any kind of discrimination between any of them. Moreover, any kind of offense will be regarded as a supreme dishonor to the Creator. In parallel with Christian perception of human being, every lay faithful is required to work for the promotion of the dignity of the individual and their rights which find their source in God himself.

The laity admittedly have varied social roles throughout their life such as conjugal, familial, political, socioeconomical etc. In each field of life, they are to proclaim the word of God in considering the common good of humanity. ${ }^{47}$ They ought to dedicate themselves to be determined witness of the faith in union with Christ, and to giving of oneself to the service of others. Their service to the society starts with the marriage and in the formation of their family which is a core of entire society. Family is the first and fundamental place to keep the social values alive. ${ }^{48}$ Therefore, the very first task of the lay faithful is to make their family aware of the identity and the responsibility that they have as a Christian. One of the chief duties of the laity is the preservation of the sanctity of family life. The sacrament of Matrimony is instituted for the laity as Holy Orders is for the clergy. Hence, the great responsibility of defending marriage, the inviolable foundation of the family, largely rests on the laity. It can be said that the quality of the family will supply the solidarity and nourishment in the society. In Familiaris Consortio, Pope John Paul II emphasizes that the path to the future passes through the family and that it is also the duty and apostolate of the laity to make the family aware of its identity as the "primary social nucleus and the basic autonomous social institution." 49

\section{- Communal mission}

The world today is a complex society which is characterized by religious and cultural pluralism. The mission in

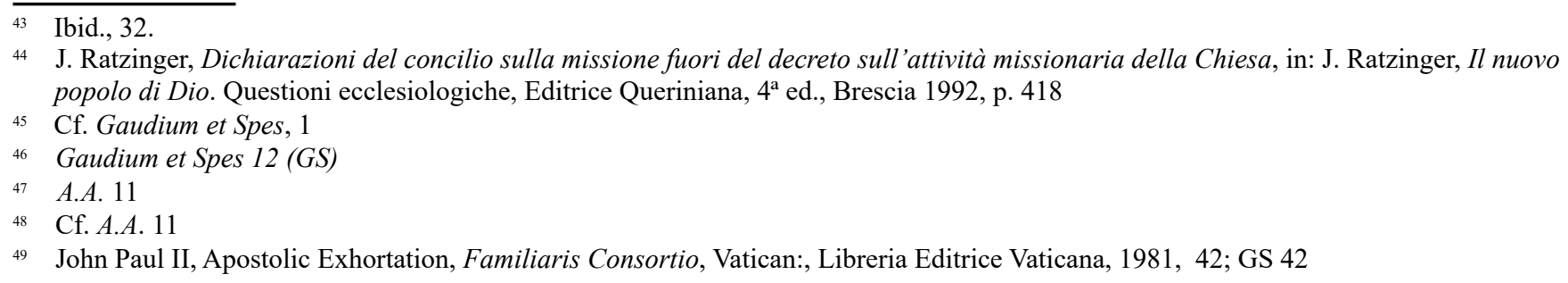


today's world obviously becomes more and more difficult and it demands no less zeal. Pope Francis notes that in this complexity of our modern society and its ongoing process of globalization that challenges our society in many ways: "the economic exclusion; money becomes a new idol; the financial system becomes more a dominant ruler than a server, and the inequalities in the societies are continuously increasing." ${ }^{50}$ Looking at these challenges facing the world require therefore a joint mission among the believers. According to Eugene Smith a communal mission is considered more effective and relevant ${ }^{51}$. The communal mission consists in two parts: the communal mission refers to the dimension of intra ecclesia and extra ecclesia. The dimension intra ecclesia is concerned with the communal mission in the Church: It is expedient for the laity to work in communion with the religious and ordained ministry for the good of the entire mission of the Church: the calling for communal mission is part of the relationality between the lay people, religious and the hierarchy.

The other dimension of the communal mission facing the pluralistic world is the role of the laity regarding extra ecclesia: Here they have to cooperate with believers from other Christian denominations, other religions, and also non-believers. ${ }^{52}$ The lay mission extra eclessia faces religious pluralism which challenges them in understanding and appreciating their ecclesial roles. We should realize that to promote a good human and societal development, the promotion of justice, human rights and peace are not only the duty of Christians but pertains principally to all people. Therefore, the decree Apostolate of Lay People Apostolicam Actuositatem, advocates that the laity work together with all those who have a good will on national and international levels for the common good. A good cooperation among believers requires attitudes and skills of dialogue, for instance by promoting helpful corporations. ${ }^{53}$

\section{- Mission as Witnessing}

The laity are witnesses and coworkers of the truth. In his book The Nature and Mission of Theology, Ratzinger explains that the "truth, in fact is the medium in which humans make contact, whereas the absence of truth closes us from one another." ${ }^{\prime 54}$ Thus, the truth is an important and essential part of human life and of all dimensions of life and societies, which means that every human being has the responsibility to search for truth and to give witness to it. to seek and live the truth is "a prior moral obligation." 55 Therefore, all the lay faithful have the duty to work for the truth and to be an agent who cares and promotes truth in the society; a task that demands a return to truthfulness and the fostering of the sense of the common good. A society that is not founded on truth cannot stand, because a society not founded on truth is either founded on lies or deceit which can provide no stable basis for human relationships and a stable social order. Thus, we must obey the biblical injunction to do the truth in love (Eph. 4:15). The laity must seek the truth, speak the truth, do the truth. This means that they must seek out what is right, speak what is right, and do what is right; and in doing so in love, in solidarity with service of others they become the salt of the earth.

There are many situations today which violate gravely the dignity of human beings: like abortion euthanasia, terrorism, exploitation, prostitution, human trafficking, environmental degradation etc. These realities oppose the truth and are rooted in sin and greed, individual and societal egoism. When the lay people assume a political function in the society they have to proclaim the Good News by promoting justice and fostering the common good of all members of a society without discrimination. The decree Apostolicam Actuositatem states the laity are called to "infuse a Christian spirit into the mentality and behavior, customs, laws and structures of the community in which one lives." ${ }^{~} 6$ When the laity are working in institutions on the national or international levels they should cooperate with other believers and even unbelievers in working for the cause of truth through advocating human rights, justice and peace.

We have stress that from their missionary mandate the lay faithful is to maintain a proper relationship between the political community and the Church. Though the Church, in the mind of Pope Francis is not expected to have ties to any political party, to perform her social doctrine, lay faithful need to be witness to safeguard human and the Gospel values such as liberty and justice, common good, love for the poor, and dedication to the solidarity, which are all related to political activity. ${ }^{57}$ In addition to prayer and community life, they must actively work for social justice, bringing the salvific word of Christ to all those who suffer.

\footnotetext{
so $\quad$ Pope Francis, Evangelii Gaudium, 44-49.

51 E. Smith, "Individualistic Evangelism is Inadequate", in N. E. Thomas (ed.) Classic Texts in Mission \& World Christianity, New York:, Orbis Books, 1995, 161-162

52 R. Panikkar, "Toward an Ecumenical Ecumenism", in N. E. Thomas (ed.) Classic Texts in Mission \& World Christianity, New York:, Orbis Books, 1995, 273.

53 A.A. $18-19$

54 J. Ratzinger, The Nature and Mission of Theology: Approaches Understanding its Role in the Light of Present Controversy, San Francisco:, Ignatius Press, 1995. 39.

55 John Paul II, Encyclical letter, Veritatis Splendor, Vatican, Libreria Editrice Vaticana, 1993, 31 \& 34

${ }_{56}$ A.A. 13

${ }^{57}$ Pope Francis, Evangelii Gaudium 201.
} 


\section{Challenges facing the Laity's Missionary Role}

Remarkably, the Second Vatican Council dogmatic constitution on the Church, Lumen Gentium quoted a famous phrase of St. Augustine: "What I am for you terrifies me; What I am with you consoles me. For you I am a Bishop, but with you I am a Christian. The former is a duty; the latter is grace. The former is a danger; the latter, salvation." ${ }^{8}$ It follows quite deductively that clericalism, a conception that sees the Church as the domain of the clergy and the world as the domain of the laity is a dangerous factor against the laity missionary role. It consequently denies them the universal call to holiness so clearly taught by Vatican II. ${ }^{59}$ The lay vocation is always devalued when clericalism is the order of the day, whether by treating lay people as inferior or by charging them with tasks and characteristics proper to the clergy. The lay apostolate is sometimes conveniently but unfortunately seen as a participation in the apostolate of the clergy. This sometimes, is due to the ignorance of correct and dynamic theology of the Church and on the differing roles of laity, clerics, and religious. While this can be true, it is also important to know that the lay apostolate can be more than a mere participation in the apostolate of the clergy. The great call of the laity, however, is fundamental to the Church's mission and cannot be abrogated: it is to bring Christ to the world from within; to evangelize it from the inside out.

Thus, too much emphasis on clericalism kills the initiative of the laity and renders them as mere passive followers convenient to those in the clerical state and thus affecting adversely the growth the true Church. B. Kloppenburg cautioned strongly that "the clergy (Priests, bishops and pope) are not the owners of the Church, neither the diocese nor the parish community; they are not masters to be served and glorified. ${ }^{60} \mathrm{He}$ continued to argue that the Second Vatican Council deliberately and constantly described them as "servants of the people of God and nothing else." 61

If the laity is to exercise co-responsibility both in the Church and in the world by virtue of its Baptism, then it needs to nurture itself and to be nurtured. It is important that a mature and committed laity be consolidated, which can make its own specific contribution to the ecclesial mission with respect for the ministries and tasks that each one has in the life of the Church and always in cordial communion with the Bishops. Additionally, Bishops and priests must do their utmost to foster the sense of the co-responsibility of the laity. The daily contact with the internal life of the Church must not lead the hierarchy and clergy to mistrust the authentic responsibility of the laity, even implicitly, nor should it lead them to reduce that responsibility merely to consultation on material or worldly matters at their convenience.

The dogmatic constitution on the Church, Lumen Gentium incisively teaches that whoever they are they are called upon as living members to expend all their energy for the growth of the Church and its continuous sanctification. ${ }^{62}$ The lay apostolate is therefore a participation in the saving mission of the church itself. Through their baptism and confirmation, all are commissioned to that apostolate by the Lord Himself. ${ }^{63}$ And this mission consists precisely and essentially in the spreading of the Kingdom of God throughout the world. ${ }^{64}$ They are to impregnate the temporal order with the spirit of the gospel. ${ }^{65}$ The Catholic Church recognizes and approves associations of the Lay Faithful. These societies and associations constitute an important element in the life and mission of the Church. They are expected to strive to promote a more perfect life among members, ${ }^{66}$ foster public worship, and learn Christian doctrine. They, through these associations should continue to animate the temporal order with the Christian spirit.

In a world where the usage of multimedia greatly abounds, the laity can harness the mass media and its many coupled opportunities in their quest to undertake evangelization since the mass media controls the minds and values of the world. The evangelization of modern culture goes far beyond just entering the field of mass media, or just using it for preaching Christ. There is need to integrate the Gospel message into the new culture realizing that there is now a new language, a new technique and a new psychology.

One very important challenge for the mission of lay people today is charitable work with the poor people: the generous work and the compassion with the poor people. There is no doubt that in today's societies, fast and useful developments are occurring. However, this progress often does not benefit all people but creates a second society, a society of marginalized and poor people, shown in the imbalance of development in today's societies, locally and globally: "there are many marginalized people behind the great globalization of the world today, they are called now to be the third world, and it is the poor that make up the majority of the population." ${ }^{67}$ Progress in the society today continues to marginalize the poor people. There are a lot of people who live in misery of life: they lose their fundamental right to live in dignity. The resolve of the global community to bring extreme poverty to an end must challenge the laity

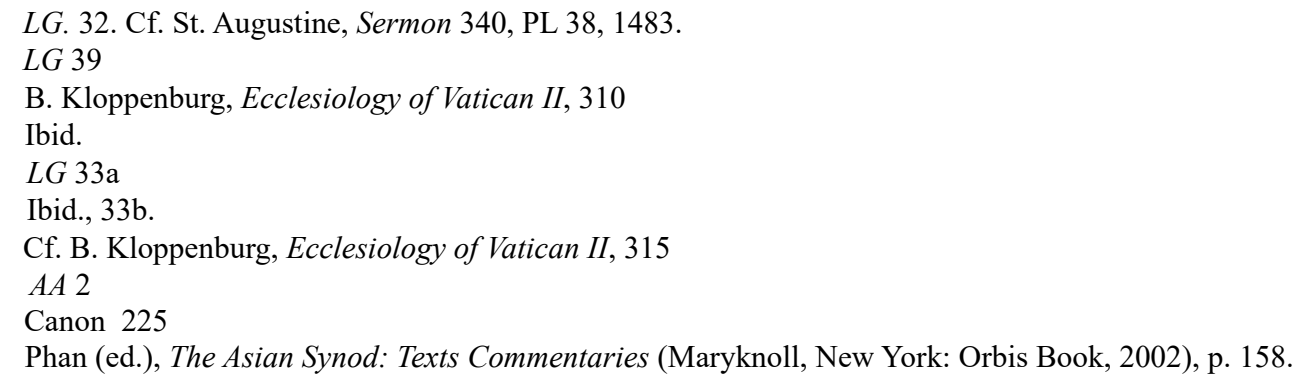


to work hard to achieve the new Sustainable Development Goals (SDGs) at an earlier timeline. The Laity are urged to educate themselves and be abreast of the contents of the bail-out package from the International Monetary Fund (IMF). All the Laity who are employers, businessmen and women are called by Jesus to help the poor and the needy as much as they can.

\section{CONCLUSION}

The Second Vatican Council made great contributions for the renewal of all aspects of the church and her mission in the modern world. These significant contributions of the Council are also manifest regarding the issue of the lay people. They are not any more merely understood as the members of the Church but they are the church themselves. Each member of the church, in communion with all contributes to build up the Body of Christ through living their vocation and functions. Thus, the lay faithful continue to have an indispensable and increasing role in the Church and in the world today.

In conclusion, the Church is not truly established and does not fully live and preach the divine message of salvation to all nations and peoples without the laity's involvement in the Church and in the world. Their calling for this mission is one of discipleship and ministry in the church and in the world. As the people of God they unite themselves with the all members of the church in the same dignity to participate properly in all missionary activities of the church in communion with all to build up the body of Christ by responding to their charisms, vocation and functions. The expertise, experience and varied talents of the lay Christian faithful are a treasure for the missionary apostolate of the Church in these modern times.

\section{BIBLIOGRAPHY}

Communique of the Plenary Assembly of The Ghana Catholic Bishops' Conference held at Bolgatanga, Upper East Region, from 6th to 14th November, 2015 On The Theme: "The Laity in the Context of the New Evangelisation" (November17, 2015).

Greenewald, M. G. "Missions, Divine", New Catholic Encyclopedia. Vol. VIII, New York et al.: McGraw Hill Book Company, 1967.

Komonchak J.A. and Collins M.,The New Dictionary of Theology, Theological Publications Bangalore: in India, 2014, 558-559

McConville, W. OFM. "Mission". The New Dictionary of Theology. Komonchak, J. A, Mary, C \& Dermot A. Lane eds. Collegeville: Minnesota, 1991.

O'Collins, G. Does Vatican II Represent Continuity or Discontinuity, in 50 years on: Probing the Riches of Vatican II, Schultenover D. G ed. Collegeville, MI: Liturgical Press, 2015.

O'Collins, G. (SJ.) \& Farrugia E., (S.J) eds., Laity, A Concise Dictionary of Theology. Quezon City: Claretian Publications, 2001, 133

Panikkar, R. Toward an Ecumenical Ecumenism, Classic Texts in Mission \& World Christianity, Norman E. Thomas ed. Maryknoll, New York: Orbis Books, 1995.

Phan C. Peter (ed . \& comp.), The Asian Synod: Texts Commentaries, Maryknoll, New York: Orbis Book, 2002.

Ratzinger, J. Dichiarazioni, del concilio sulla missione fuori del decreto sull'attività missionaria della Chiesa, in: $J$. Ratzinger, Il nuovo popolo di Dio. Questioni ecclesiologiche, Editrice Queriniana, $4^{\mathrm{a}}$ ed., Brescia, 1992.

Ratzinger, J. The Nature and Mission of Theology: Approaches Understanding its Role in the Light of Present Controversy, Adrian Walker (trans.) San Francisco: Ignatius Press, 1995.

Roberts A., Donaldson J. \& Cleveland, A.C., Ante-Nicene Fathers, New York: Christian Literature Publishing Co., $1885,3$.

Smith, E. "Individualistic Evangelism is Inadequate", Classic Texts in Mission \& World Christianity, Norman E. Thomas ed., Maryknoll, New York: Orbis Books, 1995.

Smith, E. "Individualistic Evangelism is Inadequate", Classic Texts in Mission \& World Christianity, Norman E. Thomas (ed.) Maryknoll, New York: Orbis Books, 1995. 